\section{Investigating a comprehensive model for evaluating occupational and environmental risks of dimensional stone mining}

The Mining-Geology-Petroleum Engineering Bulletin UDC: $622.8,331.4$

DOI: $10.17794 /$ rgn.2020.1.8

Original scientific paper

\author{
Mojtaba Yari'; Raheb Bagherpour'; Mehrbod Khoshouei'; Hossein Pedram \\ ${ }^{1}$ Department of Mining Engineering, Isfahan University of Technology, Isfahan, Iran.
}

\begin{abstract}
One of the most hazardous fields of engineering is mining operations and accordingly, it requires extra consideration on risk evaluation. Decorative stone quarrying is one of the main branches of the mining industry in Iran. Currently, Iran, China and Italy are known as the three main producers of decorative stones in the world. Subsequently, risk assessment is one of the main steps of quarrying organization. One of the main steps of risk assessment is Risk Breakdown Structure (RBS). In order to achieve this goal, a comprehensive structure of dimensional stone quarrying is modelled in this research and divided into 17 main levels. One of the most useful procedures of risk ranking is Multi attribute decisionmaking methods which state that they have numerous affecting parameters. In the next step of this study, the main hazards of main decorative stone quarrying are assessed by implementing the 'Preference Ranking Organization Method for Enrichment Evaluation' (PROMETHEE) technique. As a final point, Economical, Management, and Schedule risks are determined as the most intimidating hazards in this field.
\end{abstract}

\title{
Keywords:
}

Risk assessment, Dimensional stone, Fuzzy-AHP, Risk Breakdown Structure, PROMETHEE

\section{Introduction}

Risk is an uncertainty, occurrence or condition and its existence has different effects on the aims of the operation, e.g. including threats and also opportunities for the project goals (Pinto, 1998). Currently, research in mining operations are dramatically influenced by dangers and any decision needs risk aspects. Risk is defined, according to the Project Risk Management standard PMBOK or Project Management Body of Knowledge as the uncertainty that may or may not have a negative impact which could cause injury or loss (Guide, 2001). Categorizing, processing and proper responding to all hazards of operation for improving impacts of wanted phenomena and decreasing unwanted events, developed a comprehensive risk management method. As mentioned in PMBOK, risk controlling projects contain six main levels: Programing, Risk management, Determining risks, Qualitative and Quantitative risk processing, Preparing proper respects to risk and Monitoring (Yari et al., 2016).

Since quarrying operations are one of the most dangerous operations (in the designing and application phases), they require extra attention for their hazardous aspects. Determining all full parameters of risk, caution regarding the impacts of hazards and ranking are basic

Corresponding author: Mojtaba Yari

m.yari@alumni.iut.ac.ir activities in risk management. Having a comprehensive risk management system leads to making reliable decisions in a limited time. It also helps in making the proper response to applied risks and in determining the negative aspects of hazards (Bagherpour et al. 2015; Yarahmadi et al. 2014). All risks of open-cast mining were determined by Steffen in 1997. In this investigation, risks of open-cast operations contain two fundamental branches: technical risks and management risks (Steffen, 1997). The determination and designation of mining equipments' risk factors was carried out by Joy in 2004. For achieving this goal, the possibility of risk was examined and the impact of risks on the production rate was discussed. As a result, all influencing risks are ranked by implementing the probability-consequence matrix (Joy, 2004). In 2004, a novel model was developed by Arends et al., for prognosticating the costs of risk evaluating in underground spaces. In this research, qualitative methods are used for risk assessment (Arends et al., 2004). Duzgun and Einstein (2004) presented a model for evaluating risks in the underground coal mines of Turkey (Duzgun and Einstein, 2004).

In 2005 “@Risk” software was applied by Heuberger for assessing the risks of gold mines using the DCF method (Heuberger, 2005). In order to complete fire risk assessment in underground excavations, Soons et al. presented a novel qualitative model in 2006 (Soons et al., 2006). 
Reilly et al. in 2007 considered the time of occurrence and the applied cost of risks. For risk assessment in underground projects (tunnels and excavations) in this research, a regression model and probability-consequence matrix are used for processing all risks (Reilly and Brown, 2004; Reilly and Parker, 2007). Evans and Brereton in 2007 indicated that both positive and negative impacts of risk should be regarded as a system. They indicated that sustainable development models should be used for the risk assessment process (Evans et al., 2007). In other research, all influencing factors of flooding in coal mines are determined in eight dominant categories in four levels of danger (Wang et al., 2008) . The Monte Carlo model is used by Fuentes for risk assessment in Chilean copper mines (Fuentes et al., 2009). All technical and economic uncertainties are explored by Dehghani and Ataee-pour for resource exploration projects. In this research, all appropriate responses to monitored risks are presented clearly (Dehghani and Ataee-pour, 2012). The previously mentioned studies proved that there is no comprehensive model for risk assessment in decorative stone quarries. In addition, the majority of previous research used the probability-consequence matrix for evaluating risks. It is proven in this investigation that these classic methods are not sufficiently reliable (Chapman and Ward, 2003). One of the main disadvantages of this process is that low possibility risks with high consequence and high probability risks with low consequence are considered equal (Pipattanapiwong, 2004).

Multi Attribute Design Making (abbr. MADM) models helps researchers to use experts' recommendations for decision-making (Pomerol and Barba-Romero, 2012; Shirland et al., 2003). MADM methods are applied for critical decision-making in mining engineering, such as equipment selection and blasting management (Yari et al., 2017; Yari et al., 2015; Yari et al. 2014). Safety factors for decorative stone quarries were examined for the first time through an analysis of different incidents and injuries which occurred. For this purpose, standard guides were implemented for safety, quality measurement and risk analysis (Bagherpour et al., 2015). A classification of quarries considering safety and environmental attributes help mining companies in all aspects of health, safety and environmental management. This process helps them to convert their qualitative assessment to quantitative evaluation and reliable judgment (Yari et al., 2016).

In the first step of this study, all hazards with an impact on the production rate of decorative stones quarries were analysed by using 21 experts' opinion as a Risk Breakdown Structure (RBS) in dimensional stone quarries in 17 main levels and 128 sublevels. In the next step, the weights of assessment factors were evaluated using Fuzzy-Analytical Hierarchy Processes (Fuzzy-AHP) based on experts' opinions. Finally, using the PROMETHEE method, all the defined hazards concerning the imposing aspects were evaluated and the most threatening risks were determined for the Ghasre dasht mine (Yari et al., 2014).

\section{Risk breakdown structure}

Risk Breakdown Structure (RBS) is implemented as a reliable method for hazard administration in prominent guides such as PMBOK. The application of RBS is comparable to Work Breakdown Structure (WBS). RBS is a pyramidal model of possible hazards which could be useful for administration to recognize all the risks of an operation. More detailed risk factors are present in the sub levels of the RBS for an exact definition of them (Iranmanesh et al., 2007). Full-detailed RBS is valuable for documentation of the hazards of engineering operations, but it is not essentially containing all the risks of the operation. Consequently, a proper RBS should be organized for each project considering its special features. Quarrying operations inherently include two main branches of risks: internal and external risks. Internal conditions of quarrying operations applies internal risks to a project and external restrictions such as economic policies which lead to external risks (Hillson, 2003). Fuentes categorizes hazards of the quarrying operations as: the geological risks, geotechnical risks, project risks, operational risks, environmental risks, marketing risks, macroeconomic risks, political risks and transaction risks (Fuentes et al., 2009; Gaurina-Međimurec and Mavar, 2017; Yarahmadi et al., 2014). The main hazards of the mining operation in Mongolia have been classified by Chinbat and Takakuwa as: Owners' economic uncertainty, weak management, technical risks, government bureaucracies, incorrect assessment of the resource, workers' carelessness, transportation in need of improvement, a lack of skilled workers, delay of equipment, government inspectors' restrictions, variations in regulations, fuel deficiency, accidents during the production process, unpredicted environmental events, inadequate investment, organization/human confrontation (Chinbat and Takakuwa, 2009). The previous studies show that there are no comprehensive categorizations of risk parameters in quarrying operations and only some of the hazard factors are regarded by previous investigations. Numerous and different types of risks that occur in quarrying operations makes this process as one of most hazardous fields of engineering. RBS is a reliable structure that includes all risks of a particular project and is applicable for all similar projects (MacDermott et al. 1996).

This investigation presented a complete RBS for dimensional stone quarries which contains two dominant branches of hazards: internal risks (including: 11 main categories and 79 sublevels (see Figure 1)) and external risks (including: 6 main groups and 49 sub-groups (see Figure 2)). 


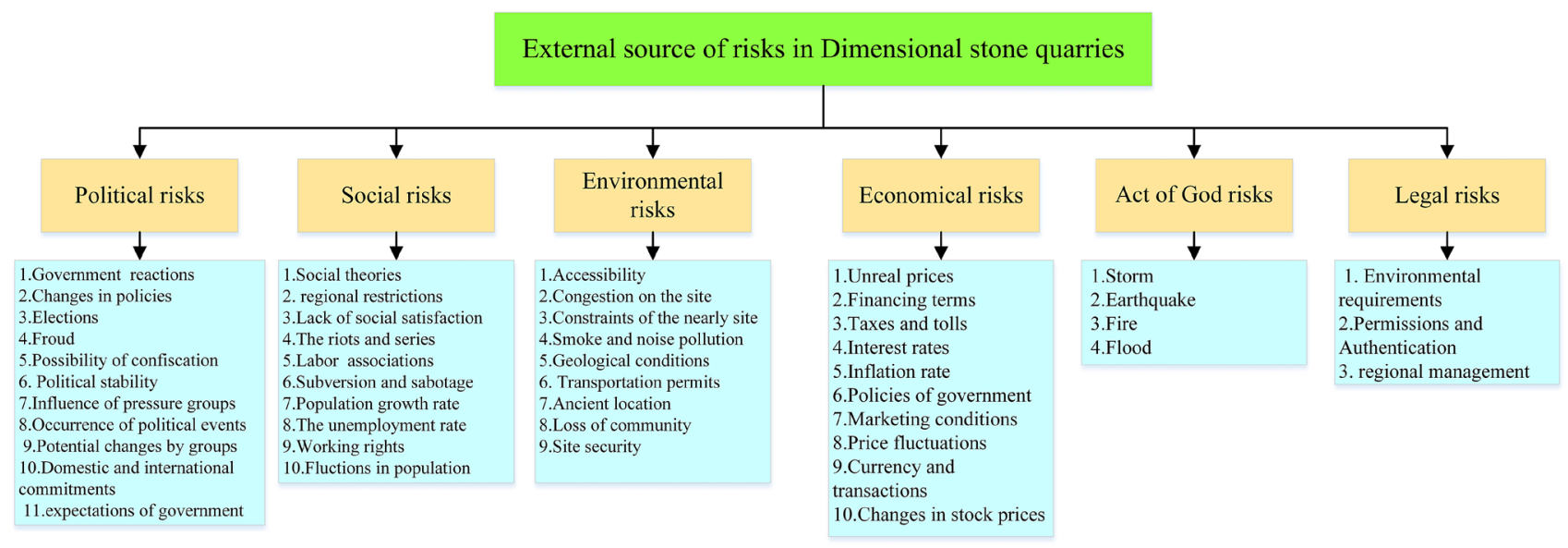

Figure 1: Risk Breakdown Structure for External hazards in dimensional stone quarries

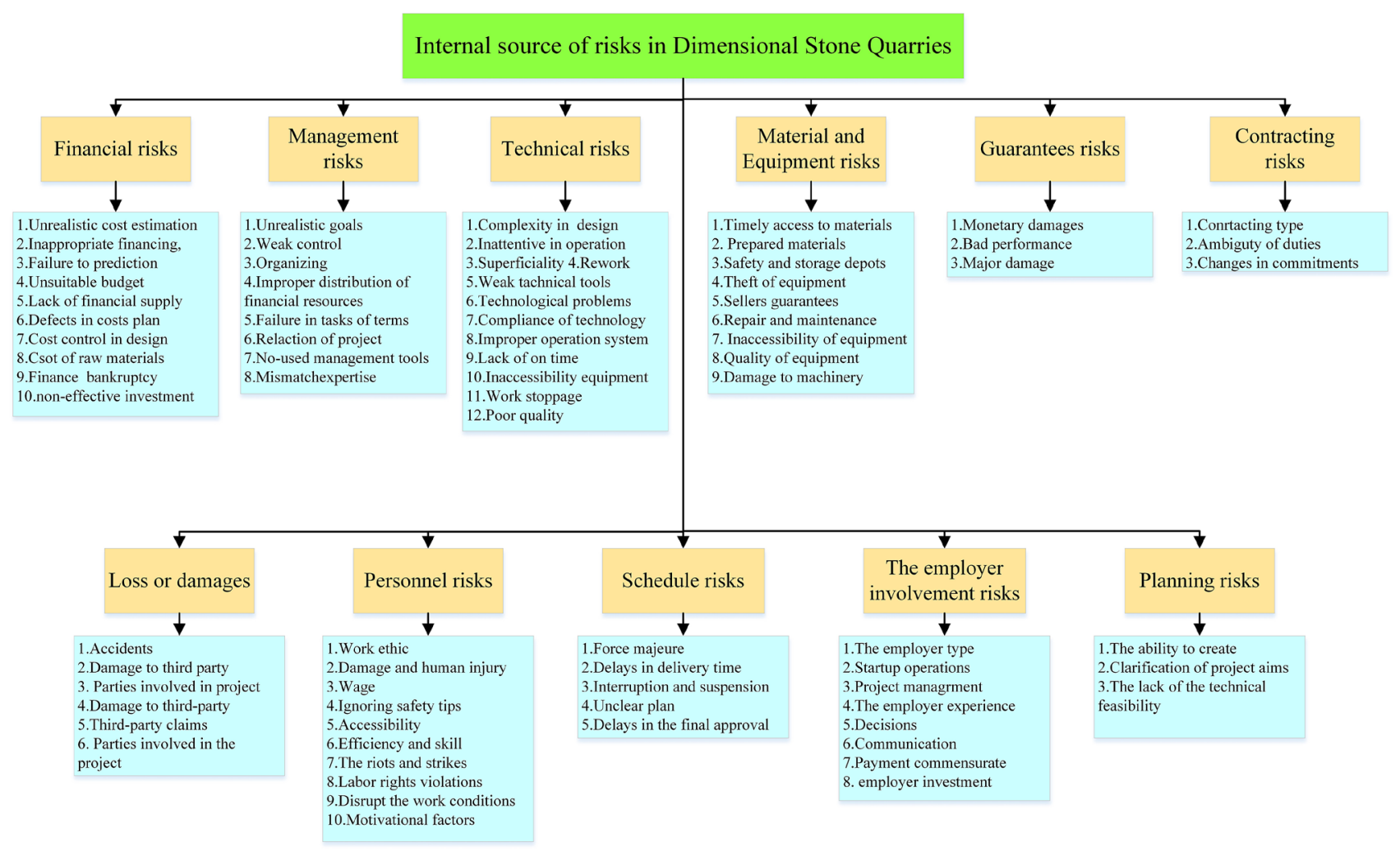

Figure 2: Risk Breakdown Structure for internal hazards in dimensional stone quarries

\section{Evaluating attributes for risk assessment}

As mentioned in the introduction, all conversional methods which are implemented for risk evaluation (such as the probability-consequence matrix) are complex models and are not able to present a comprehensive risk management model (Yari et al., 2015). For providing a comprehensive model, all impactful factors and criteria on risk assessment are determined (as shown in Table 1).

\section{Multi attribute decision-making methods}

Multi Attribute Decision Making (MADM) is a systematic model for assessing, sorting and determining the most proper alternative among several conditions. In all MADM problems, there are two main indexes: attributes and alternatives. A decision matrix is a structure which determines the value of each alternative in the perspective of attributes (Yari et al., 2016; Yoon and Hwang, 1995). All columns of the decision matrix have a scale 
Table 1: Significant attributes in risk assessment procedure for dimensional stone quarries

\begin{tabular}{|l|l|}
\hline Attribute & Description \\
\hline Event probability & $\begin{array}{l}\text { Expert judgment about the Expected } \\
\text { rate of Event risk }\end{array}$ \\
\hline $\begin{array}{l}\text { Impact on project } \\
\text { time }\end{array}$ & $\begin{array}{l}\text { Negative effect of risk on the project } \\
\text { time }\end{array}$ \\
\hline $\begin{array}{l}\text { Impact on project } \\
\text { cost }\end{array}$ & $\begin{array}{l}\text { Negative effect of risk on the project } \\
\text { cost }\end{array}$ \\
\hline $\begin{array}{l}\text { Impact on project } \\
\text { quality }\end{array}$ & $\begin{array}{l}\text { Negative effect of risk on the project } \\
\text { quality }\end{array}$ \\
\hline $\begin{array}{l}\text { Impact on project } \\
\text { performance }\end{array}$ & $\begin{array}{l}\text { Negative effect of risk on the project } \\
\text { performance }\end{array}$ \\
\hline Manageability & $\begin{array}{l}\text { The ability to manage and answer to } \\
\text { risk }\end{array}$ \\
\hline $\begin{array}{l}\text { Continually } \\
\text { repeating Exposure }\end{array}$ & $\begin{array}{l}\text { Repetition rate of risk facing the } \\
\text { ability to predict risk occurrence }\end{array}$ \\
\hline Proximity & Proximity of time of the risk occurring \\
\hline Confidence level & $\begin{array}{l}\text { confidence level of assessed risk } \\
\text { values }\end{array}$ \\
\hline
\end{tabular}

and unit. Attributes are divided into two categories: positive and negative. After applying a routine of systematic steps, attributes get their own score based on the evaluated criteria (Yoon and Hwang, 1995).

\subsection{Fuzzy-AHP method and steps}

In a decision-making problem, there are various attributes (criteria) with different important values. These values are specified by a number between 0 and $\mathrm{Y}$ and indicate the preference of each attribute in comparison with others. These indexes are called weights in decision-making problems. In this study, the Fuzzy-AHP method is implemented for calculating the relative preference of attributes under the condition of uncertainty (Ooriad et al., 2018). For applying this method, the relative preference of each attribute in comparison with other attributes is determined by using a couple comparison matrix. After carrying out the systematic stages, the weights of the attributes are determined.

The decision-making is a problem which has a number of attributes with various degrees of importance. Consequently, each attribute is assumed a weight and the preference of each index over the other attributes is determined using these weights. There are different methods for measuring the weights of the attributes. In this study, the Fuzzy-AHP method was used due to its comprehensive application (Saaty and Vargas, 2000).

Fuzzy-AHP follows all steps of the AHP method in a Fuzzy environment. In other words, this model is presented for solving decision-making problems in conditions where there is no capability of using crisp numbers. In this condition, the fuzzy environment converts all linguistic factors to fuzzy numbers. The Fuzzy-AHP model consists of the following steps (Özdağoğlu and Özdağoğlu, 2007):

\subsubsection{Break down the complex problem}

Break down the complex problem into a graded structure form.

\subsubsection{Forming a couple comparison matrix}

Forming a pair comparison matrix with $n$ rows and $m$ columns (shown in Equation 1).

$$
\left[\begin{array}{ccccc}
\tilde{1} & \tilde{a}_{12} & \tilde{a}_{13} & \ldots & \tilde{a}_{1 n} \\
1 / \tilde{a}_{12} & \tilde{1} & \ldots & \ldots & \ldots \\
1 / \tilde{a}_{13} & \ldots & \tilde{1} & \ldots & \ldots \\
\ldots & \ldots & \ldots & \ldots & \ldots \\
1 / \tilde{a}_{1 n} & 1 / \tilde{a}_{2 n} & \ldots & \ldots & \tilde{1}
\end{array}\right]
$$

Where:

$$
\tilde{a}_{i j}= \begin{cases}1 & i=j \\ \tilde{1}, \tilde{3}, \tilde{5}, \tilde{7}, \tilde{9} \text { or } \tilde{1}^{-1}, \tilde{3}^{-1}, \tilde{5}^{-1}, \tilde{7}^{-1}, \tilde{9}^{-1} & i \neq j\end{cases}
$$

4.1.3. Calculating fuzzy synthetic amount

$$
S_{i}=\sum_{j=1}^{m} M_{g_{i}}^{j} *\left[\sum_{i=1}^{n} \sum_{j=1}^{m} M_{g_{i}}^{j}\right]^{-1}
$$

Calculating the fuzzy synthetic amount value $s_{i}$ four rows of pairwise comparison matrix as shown in Equation 2.

Where:

$M_{g_{i}}^{j}$ - triangular fuzzy numbers,

$s_{\mathrm{i}}$ - fuzzy synthetic amount value,

$i$ - each of the attributes,

$\mathrm{j}$ - each of the criteria,

$\mathrm{m}$ - number of criteria,

$\mathrm{n}$ - number of attributes.

To get $\sum_{j=1}^{m} M_{g_{i}}^{j}$ perform "fuzzy addition operation" of $m$ extent analysis values for a particular matrix given in Equation 3.

$$
\sum_{j=1}^{m} M_{g_{i}}^{j}=\left(\sum_{j=1}^{m} l, \sum_{j=1}^{m} m_{j}, \sum_{j=1}^{m} u_{j}\right)
$$

Where:

$l$ - the lower limit value,

$m$ - the most promising value,

$u$ - the upper limit value.

To obtain $\sum_{i=1}^{n} \sum_{j=1}^{m} M_{g_{i}}^{j}$ perform the "fuzzy addition operation" of $M_{g_{i}}^{j}(\mathrm{j}=1,2, \ldots, \mathrm{m})$ values are given as Equation 4. 


$$
\sum_{i=1}^{n} \sum_{j=1}^{m} M_{g_{i}}^{j}=\left(\sum_{i=1}^{n} l_{i}, \sum_{i=1}^{n} m_{i}, \sum_{i=1}^{n} u_{i}\right)
$$

And then calculate the reverse of the vector (see Equation 5).

$$
\left[\sum_{i=1}^{n} \sum_{j=1}^{m} M_{g_{i}}^{j}\right]^{-1}=\left(1 / \sum_{i=1}^{n} u_{i}, 1 / \sum_{i=1}^{n} m_{i}, 1 / \sum_{i=1}^{n} l_{i}\right)
$$

\subsubsection{Defining the degree of possibility}

The degree of possibility of $M_{2}=\left(1_{2}, \mathrm{~m}_{2} \cdot \mathrm{u}_{2}\right) \geq M_{1}=$ $=\left(l_{1}, m_{1} \cdot u_{1}\right)$ is defined in Equation 6 (Zhu et al., 1999) (see Figure 3).

$$
V\left(M_{2} \geq M_{1}\right)= \begin{cases}1 & \text { if } \mathrm{m}_{2} \geq \mathrm{m}_{1} \\ 0 & \text { if } \mathrm{l}_{1} \geq u_{2} \\ \left(l_{1}-u_{2}\right) /\left(m_{2}-u_{2}\right)-\left(m_{1}-l_{1}\right) & \text { otherwise }\end{cases}
$$

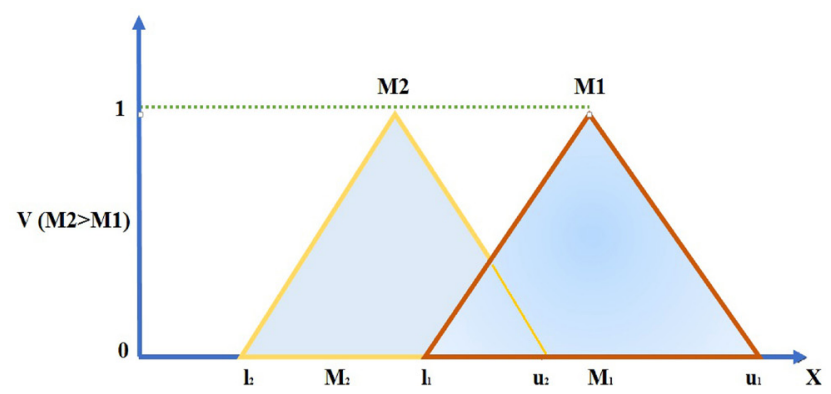

Figure 3: The degree of opportunity of two fuzzy numbers

The degree possibility for a curved fuzzy number to be greater than $\mathrm{k}$ convex fuzzy numbers $M_{i}(i=1,2, \ldots, k)$ can be defined in Equation 7.

$$
\begin{gathered}
\mathrm{V}\left(M \geq M_{1}, \mathrm{M}_{2}, \ldots, M_{k}\right)=V\left[\left(M \geq M_{1}\right)\right. \\
\text { and } \left.\left(\mathrm{M} \geq \mathrm{M}_{2}\right) \text { and }\left(\mathrm{M} \geq \mathrm{M}_{k}\right)\right]=\min V\left(M \geq M_{1}\right), \\
i=1,2, \ldots, k
\end{gathered}
$$

Where:

$M_{i}$ - convex fuzzy numbers.

\subsubsection{Calculating the weights of attributes}

$$
\mathrm{d}^{\prime}\left(A_{i}\right)=\min \mathrm{V}\left(S_{i} \geq S_{k}\right), \mathrm{k}=1,2, \ldots, n, \mathrm{k} \neq \mathrm{i}
$$

Calculating the weights of attributes in pair wise comparisons matrix (see Equations 8 and 9).

Then the weight vector is given by:

$$
\mathrm{W}^{\prime}=\left(\mathrm{d}^{\prime}\left(A_{1}\right), \mathrm{d}^{\prime}\left(A_{2}\right), \ldots, \mathrm{d}^{\prime}\left(A_{n}\right)\right)^{T}
$$

Where:

$W$ - the weight vector,

$A_{i}(i=1,2, \ldots, n)$ - attributes.

\subsubsection{Presenting the normalized weight vectors}

$$
\mathrm{W}=\left(\mathrm{d}\left(A_{1}\right), \mathrm{d}\left(A_{2}\right), \ldots, \mathrm{d}\left(A_{n}\right)\right)^{T}
$$

Via normalization, the normalized weight vectors are presented in Equation 10.

Where:

$W$ - normalized weight vector,

$A_{i}(i=1,2, \ldots, n)-\mathrm{n}$ attributes.

To evaluate the risks, experts only choose the related linguistic variable, and for calculations, they are converted into the following scale, with triangular fuzzy numbers advanced and are quantified as shown in Table 2 (Chang, 1996).

Table 2: Fuzzy number of linguistic variables

\begin{tabular}{|l|c|}
\hline Linguistic & Fuzzy number \\
\hline Very High & $(5,7,9)$ \\
\hline High & $(3,5,7)$ \\
\hline Medium High & $(1,3,5)$ \\
\hline Medium & $(1,1,3)$ \\
\hline Medium Low & $(1 / 5,1 / 3,1)$ \\
\hline Low & $(1 / 7,1 / 5,1 / 3)$ \\
\hline Very Low & $(1 / 9,1 / 7,1 / 5)$ \\
\hline
\end{tabular}

\subsection{PROMETHEE method}

The PROMETHEE (Preference Ranking Organization Method for Enrichment Evaluations) is one of the most reliable methods of MADM for the ranking of alternatives in decision-making problems. This model was presented by Brans et al. in 1984 and 1986 for the first time (Brans et al., 1986; Mareschal et al., 1984). In this method, various preference relations are determined for evaluation criteria (Dağdeviren, 2008; Senvar et al., 2014). This decision model is one of the most userfriendly models of MCDM. This method is a proper algorithm for problems with a limited number of alternatives and a set of criteria (Albadvi et al., 2007; Bilsel et al., 2006; Tuzkaya et al., 2010).

The advantages of this method are mentioned as follows:

1. The simplicity of this method for decision-making.

2. This model is applicable for real problems.

3. In partial and total decision problems PROMETHEE makes adequate, simple and reliable decisions.

Two substantial types of data are necessary for decision-making using PROMETHEE (Macharis et al., 2004):

4. The weight of criteria which indicates the relative preference of them.

5. The standard guides which experts use for determining the relative preference of alternatives for each criterion. 


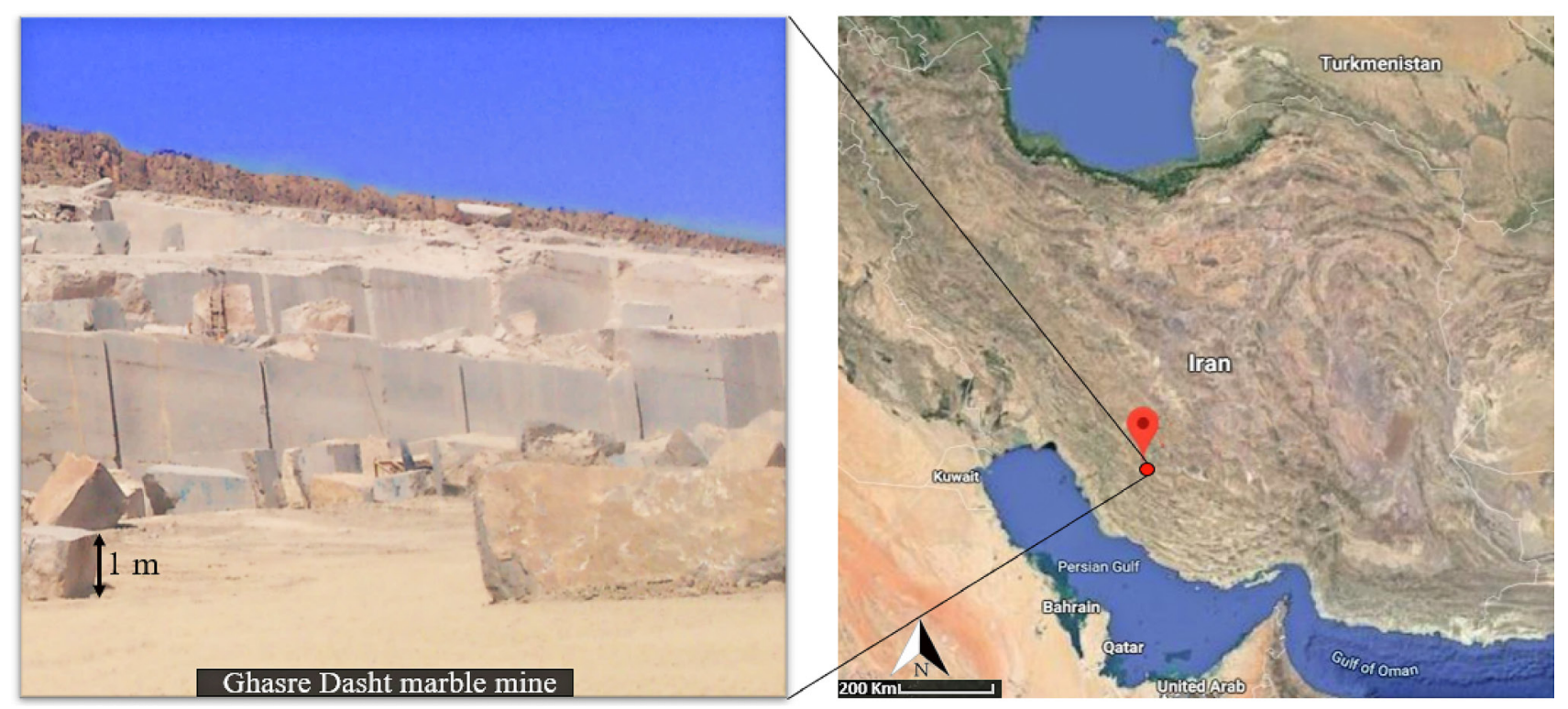

Figures 4: Ghasre dasht mine

The fundamental steps of PROMETHEE contain six main stages (Brans et al., 1986; Geldermann et al., 2000):

Step 1: defining a preference function $p j(d)$ for criterion $j$.

Step 2: determining the weights vector for the criteria.

Step 3: equation $\pi$ should be determined for all criteria $\mathrm{a}_{\mathrm{t}}, \mathrm{a}_{\mathrm{t}^{\prime}} \in A$ (see Equation 11).

$$
\pi:\left\{\begin{array}{l}
A \times A \rightarrow[0,1] \\
\pi\left(a_{t}, a_{t^{\prime}}\right)=\sum_{k=1}^{k} w_{k} \cdot\left(p_{k}\left(f_{k}\left(a_{t}\right)\right)-f_{k}\left(a_{t^{\prime}}\right)\right)
\end{array}\right.
$$

$\pi\left(a_{t}, a_{t}\right)$ as a preference indicator presents the preference degree of experts in comparison of $\mathrm{a}_{\mathrm{t}}$ and alternatives $\mathrm{a}_{\mathrm{t}}$.

Step 4: $\varnothing^{+}(a)$ leaving flow should be calculated as an index for determining power of alternatives (see Equation 12).

Where:

$$
\phi^{+}\left(a_{t}\right)=\frac{1}{T-1} \cdot \sum_{\substack{t^{\prime}=1 \\ t^{\prime \neq t}}}^{n} \pi\left(a_{t}, a_{t^{\prime}}\right)
$$

$\varnothing^{+}\left(a_{t}\right)$ - leaving flow.

$$
\phi^{-}\left(a_{t}\right)=\frac{1}{T-1} \cdot \sum_{\substack{t^{\prime}=1 \\ t^{\prime} \neq t}}^{n} \pi\left(a_{t^{\prime}}, a_{t}\right)
$$

Step 5: $\varnothing\left(a_{t}\right)$ (entering flow) should be determined as an index for weakness of alternatives (see Equation 13). Where:

$\varnothing\left(a_{t}\right)$ - entering flow.

Step 6: a graphical assessment of the sorting equation is derived. Basically, the higher the leaving flow and the lower of the entering flow, the more proper the action. These outcomes are indicated graphically using a rela- tive preorder (PROMETHEE I) or an entire preorder (PROMETHEE II).

In PROMETHEE I, alternative $a_{t}$ is raised to $a_{t^{\prime}}$ (see Equation 14) (Dağdeviren, 2008).

$$
\begin{aligned}
& \phi^{+}\left(a_{t}\right) \geq \phi^{+}\left(a_{t}^{\prime}\right) \text { and } \phi^{-}\left(a_{t}\right) \leq \phi^{-}\left(a_{t^{\prime}}\right) \text { or } \\
& a_{t} P a_{t^{\prime}}: \phi^{+}\left(a_{t}\right) \geq \phi^{+}\left(a_{t}^{\prime}\right) \text { and } \phi^{-}\left(a_{t}\right)=\phi^{-}\left(a_{t^{\prime}}\right) \text { or } \\
& \phi^{+}\left(a_{t}\right)=\phi^{+}\left(a_{t}^{\prime}\right) \text { and } \phi^{-}\left(a_{t}\right) \leq \phi^{-}\left(a_{t^{\prime}}\right)
\end{aligned}
$$

\section{Case study}

The case study which was used for verifying the presented model is a high production rate marble quarry in the north-east of the Fars Province, Iran (see Figure 4). This area contains a satisfying marble resource in the North West-South East trend. This region also includes Bangestan marls.

\section{Results and discussion}

For accumulating experts' assessments, two types of questionnaires were composed:

- The first questionnaire: defining the weights of criteria by implementing the Fuzzy-AHP method.

- The second questionnaire: for creating an initial decision matrix for assessing and sorting the determined risk by using PROMETHEE.

All questionnaires were designed and filled in accordance with the standards of the AHP and PROMETHEE methods.

The initial decision matrix contains 11 columns and 18 rows which includes criteria and alternatives respectively. The opinions of 21 decorative stone experts were gathered for filling the initial decision matrix accurately. By using Fuzzy-AHP, the weights (relative importance) 


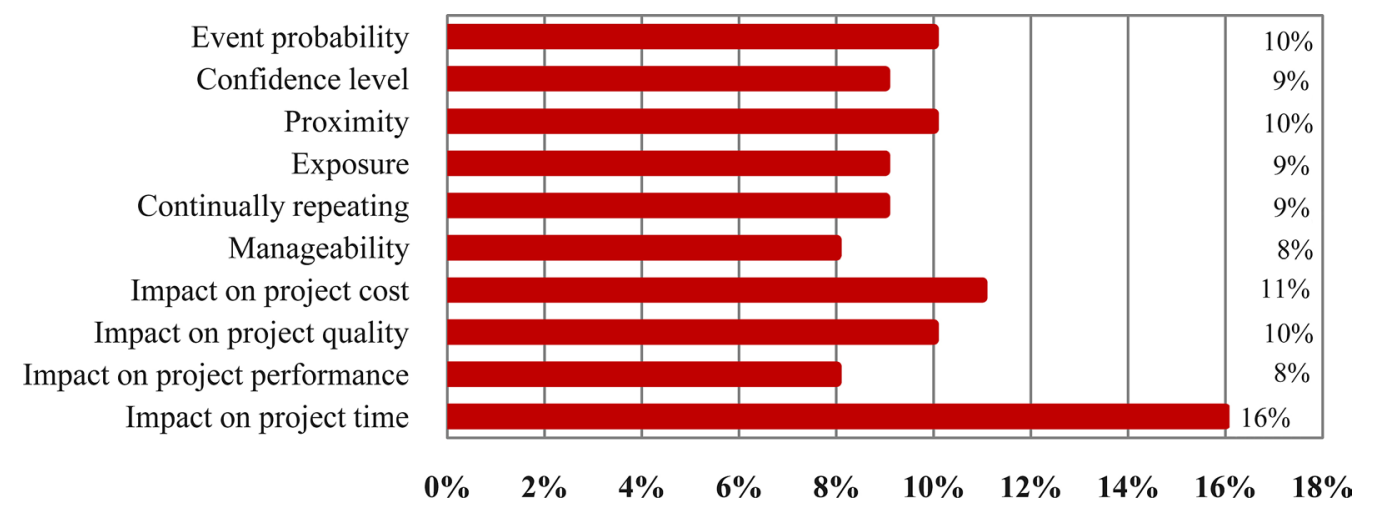

Figure 5: Weights of criteria

of criteria were determined. Figure 5 shows the relative importance of the criteria in this study.

In the next stage, by forming an initial decision matrix and determining the weights of criteria, graphic PROMETHEE software was applied for the sorting and evaluating of risks. All stages of PROMETHEE were consequently followed and the results are presented in Table 3. Later assessing the weight of attributes and applying all the mentioned steps of the PROMETHEE method, the ranking process of risks is shown by using the Graphic PROMETHEE Software. Figure 6 and Table 3 show the results of PROMETHEE for sorting threatening risks of the Ghasre dasht marble quarry.

The mining process is one of the unrepeatable processes that affect different factors and conditions of op-

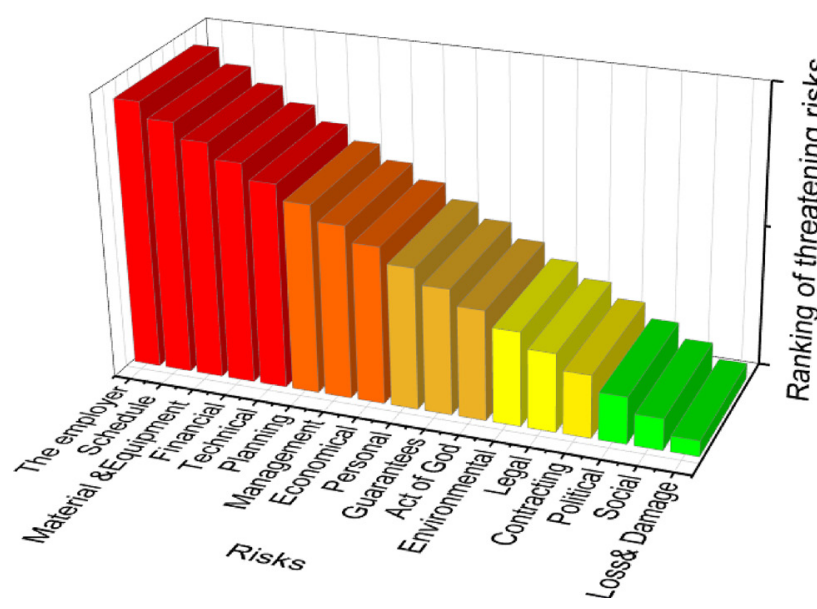

Figure 6: Sorting threatening risks of the Ghasre dasht marble quarry erations. Therefore, the risks in different mines are different. The results obtained in this study are only related to dimensional stone quarries.

\section{Conclusion}

Quarrying and extracting operations are the riskiest and most hazardous operations in mining. The assessment, controlling and management of risks in quarrying regions are significant issues which could lead to sustainable production. Categorizing, processing and proper responding to all hazards of the operation for improving the impacts of wanted phenomena and decreasing unwanted events, lead to the development of a comprehensive risk management method. The Risk Breakdown Structure process is an applicable and helpful means of risk evaluation. In this research, decorative stone quarrying risks are explored for the first time and divided into 17 main branches and 127 subcategories. These risks are political risks, social risks, environmental risks, economical risks, act of God risks, legal risks as external sources and financial risks, management risks, technical risks, material and equipment risks, contracting risks, loss or damage, personnel risks, schedule risks, employer involvement risks and planning risks as internal risks. After determining the main and sublevel risks, these hazards are ranked by using PROMETHEE by regarding all the influencing criteria of risk assessment. The opinions of 21 decorative stone experts were gathered for filling the initial decision matrix accurately. By using Fuzzy-AHP, the weights of criteria are determined. The results indicate that the employer risk is in the first rank

Table 3: Results of PROMETHEE for sorting threatening risks of the Ghasre dasht marble quarry

\begin{tabular}{|l|l|l|l|l|l|}
\hline Risk & Rank & Risk & Rank & Risk & Rank \\
\hline Employer risk & 1 & Management risk & 7 & Legal risk & 13 \\
\hline Schedule risk & 2 & Economical risk & 8 & Contracting risk & 14 \\
\hline Material and Equipment risk & 3 & Personal risk & 9 & Political risk & 15 \\
\hline Financial risk & 4 & Guarantees risk & 10 & Social risk & 16 \\
\hline Technical risk & 5 & Act of God risk & 11 & Loss and Damages risk & 17 \\
\hline Planning risk & 6 & Environmental risk & 12 & & \\
\hline
\end{tabular}


of risks which should be controlled in quarrying operations. Schedule risk, Material and Equipment risk, Financial risk and Technical risk are the next five most hazardous risks.

\section{References}

Albadvi, A., Chaharsooghi, S. K., and Esfahanipour, A. (2007): Decision making in stock trading: An application of PROMETHEE. European journal of operational research, 177, 2, 673-683.

Arends, G., Bielecki, R., Castle, J., Drabek, S., Haack, A., Nedbal, F., Sterling, R. (2004): Risk Budget management in progressing underground works: International Society for Trenchless Technology (ISTT) and International Tunnelling Association (ITA) Joint Working Group Report. Tunnelling and underground space technology, 19, 1, 29-33.

Bagherpour, R., Yarahmadi, R., Khademian, A., and Almasi, S. N. (2015): Safety survey of Iran's mines and comparison to some other countries. International journal of injury control and safety promotion, 1-7.

Bilsel, R. U., Büyüközkan, G., and Ruan, D. (2006): A fuzzy preference-ranking model for a quality evaluation of hospital web sites. International Journal of Intelligent Systems, 21, 11, 1181-1197.

Brans, J.-P., Vincke, P., and Mareschal, B. (1986): How to select and how to rank projects: The PROMETHEE method. European journal of operational research, 24, 2, 228-238.

Chang, D.-Y. (1996): Applications of the extent analysis method on fuzzy AHP. European journal of operational research, 95, 3, 649-655.

Ward, S., \& Chapman, C. (2003): Transforming project risk management into project uncertainty management. International journal of project management, 21, 2, 97-105.

Chinbat, U., and Takakuwa, S. (2009): Using simulation analysis for mining project risk management. Paper presented at the Proceedings of the 2009 Winter Simulation Conference (WSC), 2612-2623.

Dağdeviren, M. (2008): Decision making in equipment selection: an integrated approach with AHP and PROMETHEE. Journal of Intelligent Manufacturing, 19, 4, 397-406.

Dehghani, H., and Ataee-pour, M. (2012): Determination of the effect of operating cost uncertainty on mining project evaluation. Resources Policy, 37, 1, 109-117.

Duzgun, H., and Einstein, H. (2004): Assessment and management of roof fall risks in underground coal mines. Safety Science, 42, 1, 23-41.

Evans, R., Brereton, D., and Joy, J. (2007): Risk assessment as a tool to explore sustainable development issues: lessons from the Australian coal industry. International Journal of Risk Assessment and Management, 7, 5, 607-619.

Fuentes, J. E., George, T., and Whittikar, J. (2009): Measuring and mitigating risk in mining operations. Paper presented at the III International Conference on Mining Innovation, 2-9.

Gaurina-Međimurec, N., and Mavar, K. N. (2017): Depleted hydrocarbon reservoirs and $\mathrm{CO} 2$ injection wells- $\mathrm{CO} 2$ leakage assessment. Rudarsko-geološko-naftni zbornik, $32,2,15-27$.
Geldermann, J., Spengler, T., and Rentz, O. (2000): Fuzzy outranking for environmental assessment. Case study: iron and steel making industry. Fuzzy sets and systems, 115, 1, 45-65.

Guide, A. (2001): Project Management Body of Knowledge (PMBOK ${ }^{\circledR}$ GUIDE). Paper presented at the Project Management Institute.

Heuberger, R. (2005): Risk analysis in the mining industry. Journal Of The South African Institute Of Mining And Metallurgy, 105, 2, 75-80.

Hillson, D. (2003): Using a risk breakdown structure in project management. Journal of Facilities management, 2, 1, 85-97.

Iranmanesh, H., Jalili, M., and Pirmoradi, Z. (2007): Developing a new structure for determining time risk priority using risk breakdown matrix in EPC projects. Paper presented at the 2007 IEEE International Conference on Industrial Engineering and Engineering Management, 999-1003.

Macharis, C., Springael, J., De Brucker, K., and Verbeke, A. (2004): PROMETHEE and AHP: The design of operational synergies in multicriteria analysis.: Strengthening PROMETHEE with ideas of AHP. European journal of operational research, 153, 2, 307-317.

Mareschal, B., Brans, J. P., and Vincke, P. (1984): PROMETHEE: A new family of outranking methods in multicriteria analysis.

Ooriad, F., Yari, M., Bagherpour, R., and Khoshouei, M. (2018): The development of a novel model for mining method selection in a fuzzy environment; case study: Tazareh Coal Mine, Semnan Province, Iran. The MiningGeology-Petroleum Engineering Bulletin (Rudarskogeološko-naftni zbornik), 33. 1, 45-53.

Özdağoğlu, A., and Özdağoğlu, G. (2007): Comparison of AHP and fuzzy AHP for the multi-criteria decision-making processes with linguistic evaluations, 6,11, 65-85.

Pinto, J. K. (1998): The Project Management Institute Project Management Handbook (Jossey-Bass Business and Management Series): Jossey-Bass Inc., Publishers.

Pipattanapiwong, J. (2004): Development of multi-party risk and uncertainty management process for an infrastructure project. Kochi University of Technology.

Pomerol, J.-C., and Barba-Romero, S. (2012): Multicriterion decision in management: principles and practice, Springer Science and Business Media, 25.

Saaty, T. L., and Vargas, L. G. (2000): Models, Methods, Concepts and Applications of the Analytic Hierarchy Process, International Series in Operations Research and Management Science, 34.

Senvar, O., Tuzkaya, G., and Kahraman, C. (2014): Multi criteria supplier selection using fuzzy PROMETHEE method. In Supply chain management under fuzziness, Springer, 21-34

Shirland, L. E., Jesse, R. R., Thompson, R. L., and Iacovou, C. L. (2003): Determining attribute weights using mathematical programming. Omega, 31, 6, 423-437.

Soons, C., Bosch, J., Arends, G., and van Gelder, P. (2006): Framework of a quantitative risk analysis for the fire safety in metro systems. Tunnelling and underground space technology, 21, 3-4. 
Steffen, O. (1997): Planning of open pit mines on a risk basis. Journal-South African Institute Of Mining And Metallurgy, 97, 47-56.

Tuzkaya, G., Gülsün, B., Kahraman, C., and Özgen, D. (2010): An integrated fuzzy multi-criteria decision-making methodology for material handling equipment selection problem and an application. Expert systems with applications, 37(4), 2853-2863.

Wang, L.-G., Miao, X.-X., Xu, D., and Yu, W. (2008): Application of quantification theory in risk assessment of mine flooding. Journal of China University of Mining and Technology, 18, 1, 38-41.

Yarahmadi, R., Bagherpour, R., and Khademian, A. (2014): Safety risk assessment of Iran's dimension stone quarries (Exploited by diamond wire cutting method). Safety Science, 63, 146-150.

Yari, M., Bagherpour, R., and Almasi, N. (2016): An Approach to the Evaluation and Classification of Dimensional Stone Quarries with an Emphasis on Safety Parameters. Rudarsko-geološko-naftni zbornik, 31, 3, 15-26.

Yari, M., Bagherpour, R., and Jamali, S. (2017): Development of an evaluation system for blasting patterns to provide ef- ficient production. Journal of Intelligent Manufacturing, 28, 4, 975-984.

Yari, M., Bagherpour, R., Jamali, S., and Asadi, F. (2015): Selection of Most Proper Blasting Pattern in Mines Using Linear Assignment Method: Sungun Copper Mine/Wybór Najodpowiedniejszego Schematu Prowadzenia Prac Strzałowych W Kopalni Miedzi Sungun Z Użyciem Metody Przyporządkowania Liniowego. Archives of Mining Sciences, 60, 1, 375-386.

Yari, M., Monjezi, M., and Bagherpour, R. (2014): A novel investigation in blasting operation management using decision making methods. Rudarsko-geološko-naftni zbornik, 29, 1, 69.

Yari, M., Monjezi, M., Bagherpour, R., and Jamali, S. (2014): Developing a mathematical assessment model for blasting patterns management: Sungun copper mine. Journal of Central South University, 21, 11, 4344-4351.

Yoon, K. P., and Hwang, C.-L. (1995): Multiple attribute decision making: an introduction, Sage publications, 104.

Zhu, K.-J., Jing, Y., and Chang, D.-Y. (1999): A discussion on extent analysis method and applications of fuzzy AHP. European journal of operational research, 116, 2, 450-456.

\section{SAŽETAK}

\section{Istraživanje sveobuhvatnoga modela za procjenu obradbenoga i okolišnoga rizika kod vađenja arhitektonsko-građevnoga kamena}

Jedna od najopasnijih inženjerskih aktivnosti jesu rudarske operacije koje stoga zahtijevaju dodatne procjene rizika. Vađenje ukrasnoga kamena jedna je od glavnih rudarskih grana u Iranu. Trenutačno su Iran, Kina i Italija tri glavna proizvođača takva kamena u svijetu. Procjena rizika među temeljnim je aktivnostima kamenoloma. Jedan od glavnih postupaka toga procesa jest procjena rizika loma strukture (RLS). S tim ciljem modelirane su makrostrukure arhitektonsko-građevnoga kamena te su podijeljene u 17 razina. Jedan od najboljih postupaka za rangiranje rizika jest višeatributna metoda donošenja odluka koja povezuje brojne zavisne parametre. Nadalje, ocijenjeni su glavni rizici u najvećim kamenolomima uporabom metode preferirajućega rangiranja za poboljšanu procjenu (MPRPP). Na kraju su izračunani ekonomski rizik te rizici upravljanja i planiranja, koji ujedno imaju najveći utjecaj na opisane aktivnosti.

\section{Ključne riječi:}

procjena rizika, arhitektonsko-građevni kamen, fuzzy-AHP, rizik loma strukture, MPRPP

\section{Author's contribution}

M. Yari and R. Bagherpour contributed to the design and implementation of the research, M. Yari and M. Khoshouei contributed to the analysis of the results and to the writing of the manuscript and $\mathbf{H}$. Pedram contributed to the writing of the manuscript. 